\title{
Electrodialytically treated MSWI fly ash use in clay bricks
}

\section{Kirkelund, Gunvor Marie; Skevi, Lorena; Ottosen, Lisbeth M.}

\section{Published in:}

Construction and Building Materials

Link to article, DOI:

10.1016/j.conbuildmat.2020.119286

Publication date:

2020

Document Version

Peer reviewed version

Link back to DTU Orbit

Citation (APA):

Kirkelund, G. M., Skevi, L., \& Ottosen, L. M. (2020). Electrodialytically treated MSWI fly ash use in clay bricks. Construction and Building Materials, 254, [119286]. https://doi.org/10.1016/j.conbuildmat.2020.119286

\section{General rights}

Copyright and moral rights for the publications made accessible in the public portal are retained by the authors and/or other copyright owners and it is a condition of accessing publications that users recognise and abide by the legal requirements associated with these rights.

- Users may download and print one copy of any publication from the public portal for the purpose of private study or research.

- You may not further distribute the material or use it for any profit-making activity or commercial gain

- You may freely distribute the URL identifying the publication in the public portal

If you believe that this document breaches copyright please contact us providing details, and we will remove access to the work immediately and investigate your claim. 


\title{
Electrodialytically treated MSWI fly ash use in clay bricks
}

\author{
Gunvor M. Kirkelund ${ }^{1 *}$, Lorena Skevi ${ }^{1 / 2 / 3}$, Lisbeth M. Ottosen ${ }^{1}$ \\ ${ }^{1}$ Department of Civil Engineering, Technical University of Denmark \\ ${ }^{2}$ School of Physics, Faculty of Sciences, Aristotle University of Thessaloniki \\ ${ }^{3}$ Department of Architecture and Civil Engineering, University of Bath (current affiliation) \\ *Corresponding author: gunki@byg.dtu.dk, Brovej, building 118, 2800 Kgs. Lyngby, Denmark
}

Abstract Fly ash from municipal solid waste incineration (MSWI) is classified as hazardous waste, due to high heavy metal and salt content. Thus, beneficial use is restricted, and the fly ash hazardousness should be reduced before testing reuse options. Electrodialytic treatment can remove heavy metals and soluble salts from an MSWI fly ash suspension by applying an electric current to the suspension and thus be used to decontaminate the MSWI fly ash. In Greenland, MSWI fly ash is stored at uncontrolled disposal sites, and a more sustainable solution for handling fly ash is needed. At the same time, most construction materials are imported from Europe to Greenland, and increased use of local materials would greatly benefit the circular economy in the area. In this study, it was investigated if local Greenlandic resources could have potential in brickmaking. Two different clays; a Danish clay (used commercially in brick production) and one Greenlandic (not used commercially) and raw and electrodialytically treated MSWI fly ash from Sisimiut, Greenland were used. Small clay discs with 0, 10, 20 and $30 \%$ substitution of clay by MSWI fly ash were fired at $1000^{\circ} \mathrm{C}$ for $24 \mathrm{~h}$. Substituting clay with fly ash generally resulted in lower technical properties of the clay discs. Nevertheless, from this initial screening, the clay discs with electrodialytically treated fly ash and Greenlandic clay showed the lowest porosity and water absorption, which could be beneficial for use as construction material in cold climates. 
Keywords: heavy metals, circular economy, secondary resources, ceramics, masonry, Arctic.

\section{Highlights}

- A Danish commercial clay was compared to a Greenlandic clay for brick production

- Electrodialytic treatment decreases salt and metal concentration in MSWI fly ash

- Electrodialytically treated MSWI fly ash can be incorporated into clay bricks

- Ca content in the clay influences $\mathrm{Cr}$ leaching from fired clay bricks

\section{Introduction}

A common practice for avoiding landfill disposal of municipal solid waste (MSW) is incineration as it reduces the mass and volume of the waste. Organic and inorganic contaminants in the waste fuel are highly concentrated in the incineration residues (fly ash, bottom ash and air pollution control residues) from the incineration process and handling of the residues can be very challenging [1, 2]. Disposal in landfills is a widely applied solution but imposes a danger on the environment as a result of the leaching of the soluble elements, which can contaminate the soil and the water resources in the area, if the leachate is not treated [3]. A more sustainable approach suggests recycling and reusing of incineration residues. Incorporation of incineration residues in building materials is gaining increased focus as a waste management practice, but also as a way to develop new construction materials to promote the use of secondary resources. Industrial wastes, like fly ash from coal combustion, silica fume and blast furnace slag are fine-grained materials with a high content in $\mathrm{CaO}, \mathrm{SiO}_{2}, \mathrm{Al}_{2} \mathrm{O}_{3}$ and other reactive minerals [4,5], and this composition is compatible with cement-based and claybased materials. Therefore, several studies investigate the application for partly replacement of cement and clay with these waste materials as secondary raw materials for the production of mortar, concrete and bricks [6-8]. The heterogeneous composition of ceramic materials, like 
clay bricks, is ideal for incorporating organic and inorganic wastes, even if they contain toxic substances, as they can be partly stabilized in the ceramic matrix and at the same time even enhance key properties of the final product [9-12]. A reduction of primary raw materials is also sought for in the circular economy, and thus research on replacing parts of clay to make brick production more sustainable is needed.

MSWI fly ash is an ultrafine material containing $\mathrm{CaO}, \mathrm{SiO}_{2}, \mathrm{Al}_{2} \mathrm{O}_{3}$ [13] and therefore it has potential to be used as clay substitution for the production of sustainable bricks. MSWI fly ash in Greenland is so far stored at uncontrolled disposal sites, before being shipped for end disposal abroad. At the same time, most construction materials used, like cement and wood, are imported from Europe to Greenland. Increased use of local materials instead, would greatly benefit the circular economy in the area. Therefore, there is a potential for using MSWI fly ash as a substitution of clay in bricks, which should stabilise the heavy metals, reduce the import of raw materials and at the same time conserve primary clay resources. Incorporation of raw MSWI fly ash in bricks has only been investigated in a few studies, where the bricks were tested for compressive strength, bending strength, water absorption, shrinkage and metal leaching [1417]. These previous studies found that both fly ash content and sintering temperature influence the performance of the bricks. Deng et al. [16] found that the bending strength in bricks with 5 wt\% MSWI fly ash was comparable to the bending strength of a raw clay brick. When using more than $10 \mathrm{wt} \%$ (and up to $25 \mathrm{wt} \%$ ) MSWI fly ash in the clay mix, the bending strength decreased with 10-25\%. The water absorption was $8.5 \%$ in the brick sample with 5 wt\% MSWI fly ash and increased to $11 \%$ in the brick sample with 25 wt\% MSWI fly ash [16]. The compressive strength was seen to decrease slightly from $16 \mathrm{MPa}$ to $15 \mathrm{MPa}$ when increasing the amount of MSWI fly ash in bricks from 20 to $25 \mathrm{wt} \%$, which also gave a $2 \%$ higher water absorption in the brick with 25 wt\% MSWI fly ash [15]. Contrarily, increasing sintering temperatures can result in decreased water absorption and increased bending strength [16] and 
compressive strength of the clay bricks [14], even with increasing MSWI fly ash content. Short time leaching of reported toxic metals (As, $\mathrm{Cd}, \mathrm{Cr}, \mathrm{Cu}, \mathrm{Hg}, \mathrm{Ni}, \mathrm{Pb}$ and $\mathrm{Zn}$ ) from new bricks with 2.5-30 wt\% MSWI fly ash complies with guideline limits [14,16,17]. Frost damages leading to internal cracking and surface scaling combined with water absorption in cold climates could result in severe deterioration of the bricks and thereby a possible release of the toxic metals from the brick matrix. Also, MSWI fly ash is classified as hazardous waste, and direct reuse is restricted in Europe [1]. Thus, proper treatment for reducing the hazardousness of the MSI fly ash is essential before considering possible beneficial uses.

Various techniques have been proposed for reducing the concentration of heavy metals and salts in MSWI fly ash [8]. Water washing is a simple method, often used as a pre-treatment before other techniques since it is suitable for removing salts and very mobile fractions of heavy metals. Other techniques which stabilize heavy metals include carbonation, chemical stabilisation and thermal and hydrothermal treatment. The electrodialytic treatment has been proposed as an alternative method for the combined removal of heavy metals and soluble salts and has been applied for the decontamination of MSWI fly ash [18,19]. The method uses an electric current applied to the waste material and this results in removal of ions in the electric field. Metal removal of $61 \% \mathrm{Cd}, 66 \% \mathrm{~Pb}$ and $53 \% \mathrm{Zn}$ and reduced chloride leaching from 21,000 mg/l to $10 \mathrm{mg} / \mathrm{l}$ in fly ash and APC residue have been reported in electrodialytic experiments lasting 14 days [18]. Use of electrodialytically treated MSWI fly ashes have been tested in brick production in laboratory scale production, but the results are conflicting. Belmonte et al. [20] tested if $20 \mathrm{wt} \%$ or $40 \mathrm{wt} \%$ raw, water-washed and electrodialytically treated MSWI fly ash could replace clay for brick production and found that the water absorption increased with fly ash use in the bricks, where the electrodialytically treated fly ash gave the highest water absorption. Also, an increase of As and Cr leaching was seen when using MSWI fly ash in the bricks. Chen et al. [21], on the other hand, found that bricks with 5-20\% 
electrodialytically treated MSWI fly ash gave lower porosity and water absorption and higher compressive strength, compared to raw MSWI fly ash. There is a need to find the optimum replacement percentage of electrodialytically treated MSWI fly ash in brick products and to verify the previous results, for this application to be feasible.

This study investigates the potential of brick production from Danish and Greenlandic clay that is partly substituted with MSWI fly ash, by screening the production on small clay discs. The effect of electrodialytic treatment of the fly ash in the final product is evaluated in comparison with clay discs with raw MSWI fly ash.

\section{Methodology}

\subsection{Experimental materials}

Two different clays were used for the clay discs; commercially available Teglværk clay (denoted T) from Wienerberger, Denmark and clay sediment sampled from Sisimiut, Greenland (denoted S). MSWI fly ash was collected from the incineration plant in Sisimiut, Greenland and was used raw (denoted R) or electrodialytically treated in the clay discs. The electrodialytic treatment was performed in both a two- and a three-compartment cell (denoted E and D respectively), to remove heavy metals from the fly ash as a treatment method. More specific information and details about the electrodialytic treatment experiments can be found in [22]. Particle size distribution and mineralogy were determined on the electrodialytically treated ashes separately, to evaluate how similar these properties were for the treated ashes, as [18] found different mineralogy for electrodialytically treated air pollution control residue by the two- and three-compartment cell. These particle distribution and mineralogy were found to be similar for the two treated ashes and therefore it was determined to mix the two ashes and for the rest of the experimental work the ashes were mixed in equal parts to ensure homogeneity in the results. The heavy metal leaching and total content were measured on an equal mix of the 
two ashes from the two-and three-compartment cells (denoted ED). All notations of the experimental materials are shown in Table 1 . All samples were dried at $50{ }^{\circ} \mathrm{C}$ for 48 hours before the analytical and experimental work.

\subsection{Analytical methods}

The Atterberg limits (liquid and plastic limits) were determined for the two clay samples to evaluate the plastic properties of the clays. The plastic limits $\left(\mathrm{W}_{\mathrm{p}}\right)$ were determined by the rolling method (ISO/TS 17892-12), and liquid limits ( $\left.\mathrm{W}_{\mathrm{L}}\right)$ were measured using the Casagrande method (DIN 18122-1). The particle size distribution was determined with a Malvern Mastersizer 2000 laser diffractometer using the dry dispersion unit. Clay and ash mineralogy was studied by X-ray powder diffraction (XRD) for identification of major crystalline phases. The instrument was a PANalytical X'Pert Pro operating at $45 \mathrm{~mA}$ and 40 $\mathrm{kV}$ applying $\mathrm{Cu} \mathrm{K} \alpha$ radiation with a $2 \Theta \mathrm{X}$ 'Celerator detector. The samples were scanned within 4-70 $2 \Theta$ for $2.5 \mathrm{~h}$. The diffractograms were interpreted using the ICDD PDF-4 database for minerals. Total $\mathrm{Ca}, \mathrm{Cd}, \mathrm{Cr}, \mathrm{Cu}, \mathrm{Pb}$ and $\mathrm{Zn}$ concentrations were measured by Inductive Coupled Plasma - Optical Emission Spectrometry (ICP-OES) after digestion according to DS 259. For the digestion, $1 \mathrm{~g}$ of material and $20 \mathrm{~mL} 7.3 \mathrm{M} \mathrm{HNO}_{3}$ were heated at $120{ }^{\circ} \mathrm{C}$ at $200 \mathrm{kPa}$ for $30 \mathrm{~min}$ in an autoclave. The digestion liquid was separated from the remaining solids through a $45 \mu \mathrm{m}$ filter and the sample diluted to $100 \mathrm{~mL}$. $\mathrm{Cd}, \mathrm{Cr}, \mathrm{Cu}, \mathrm{Pb}$ and Zn leaching was performed in a modified version of DS/EN 12457-1 (L/S 2), where 15 g ash was mixed with $30 \mathrm{~mL}$ distilled water (instead of $2 \mathrm{~kg}$ and $40 \mathrm{~L}$ as described in the standard) and suspended for 24 hours, before $\mathrm{pH}$ was measured in the suspension, filtration of the suspension and measurement of the elements in the eluate by ICP-OES. $\mathrm{Cl}$ and $\mathrm{SO}_{4}$ anions were measured on the leaching samples by ion chromatography.

\subsection{Production of clay discs}


Twelve different clay mixtures with ash were made and compared to clay without fly ash (Table 2). Clay was replaced by 10, 20 and $30 \mathrm{wt} \%$ of either raw or electrodialytically treated fly ash in the mixture and small brick specimens in the form of discs were produced following the method that was applied in a previous study [20]. According to this method, the materials were mixed with a total weight of $2.3 \mathrm{~g}$ material, and distilled water was added to the material to obtain a paste-like texture. The mixture then absorbed the moisture for $24 \mathrm{~h}$. Next, the clay mixture was pressed into discs mechanically (Instron 6022), under a maximum load of $10 \mathrm{KN}$, equivalent to 31.8 MPa forming pressure. The produced discs weighed approximately $2 \mathrm{~g}$ while their diameter and thickness (height) were around $20 \mathrm{~mm}$ (diameter of the mould) and $3 \mathrm{~mm}$, respectively. Five discs of each mixture were produced, and their exact dimensions and weight was immediately measured with a micrometre scale gauge and a precision balance. The discs were then dried at $105^{\circ} \mathrm{C}$ for $24 \mathrm{~h}$, and the dimensions and weight of the dried discs were again measured. Finally, the discs were fired at $1000^{\circ} \mathrm{C}$ for $24 \mathrm{~h}$, and their dimension characteristics were again measured. The loss of mass (ML) and the linear shrinkage (LS) was determined between the wet, dry and fired condition, the total mass loss (TML) and total linear shrinkage (TLS) from wet to fired condition as described in the following equations. $\mathrm{X}$ is the diameter when referring to linear shrinkage and the mass when referring to the loss of mass.

$$
\begin{aligned}
& D L S(\text { or } D M L)=\frac{x_{w e t}-x_{d r y}}{x_{w e t}} \times 100 \% \\
& F L S(\text { or } F M L)=\frac{x_{d r y}-x_{\text {fired }}}{x_{\text {dry }}} \times 100 \% \\
& T L S(\text { or } T M L)=\frac{x_{\text {wet }}-x_{\text {fired }}}{x_{\text {wet }}} \times 100 \%
\end{aligned}
$$

Where:

DLS - dry linear shrinkage

FLS - fired linear shrinkage 
DML - dry mass loss

FML - fired mass loss

TLS- total linear shrinkage

TML- total mass loss

The open porosity, dry density and water absorption were determined according to the procedure Ti-B-25 by the Danish Technical Institute. The discs were dried at $105^{\circ} \mathrm{C}$, cooled to room temperature in a desiccator and weighed $\left(m_{d r y}\right)$. The discs were placed in a vacuum in a desiccator for $3 \mathrm{~h}$, thereafter distilled water was added until the discs were submerged. The vacuum was again added for $1 \mathrm{~h}$, thereafter the vacuum was released and the submerged discs were left at atmospheric pressure overnight. The water-saturated discs were then weighed in water $\left(\mathrm{m}_{\mathrm{sw}}\right)$ and air $\left(\mathrm{m}_{\mathrm{sa}}\right)$ after being wiped for excess water. The open porosity, dry density and water absorption were then calculated as:

$$
\begin{gathered}
\text { Open porosity }=\frac{m_{s a}-m_{d r y}}{m_{s a}-m_{s w}} \cdot 100 \% \\
\text { Dry density }=\frac{m_{d r y} \cdot \rho_{w}}{m_{s a}-m_{s w}} \cdot 100 \% \\
\text { Water absorption }=\frac{m_{s a}-m_{d r y}}{m_{d r y}} \cdot 100 \%
\end{gathered}
$$

Where $\rho_{w}$ is the water density at room temperature.

Mineralogy (XRD) and heavy metal leaching were performed on crushed clay discs after firing.

\section{Results and discussion}

\subsection{Characteristics of experimental materials}


Geotechnical properties of the clays are shown in Table 3 and the particle size distribution of the raw materials, clays and treated fly ashes is shown in Fig. 1 . The plasticity index $\left(\mathrm{I}_{\mathrm{P}}=\mathrm{W}_{\mathrm{L}}\right.$ $\mathrm{W}_{\mathrm{p}}$.) can be used to evaluate the span between the plastic and the liquid limits. Both clays used in this study presented low plasticity, especially the Sisimiut clay, which has a very low plastic index $(<10)$. This agrees with results found by Belmonte et al. [20] for Greenlandic clay from Ilulissat and indicates that the moulding range of the Greenlandic clays is very limited. On the other hand, Belmonte et al. [20] found higher plasticity index for mixtures of clay with fly ash than the clay itself, and the moulding of the clay discs in the present study with fly ash was not more difficult in practice than with the clay itself. The two treated fly ashes, E and D, had similar particle size distribution as seen in Fig. 1. Also, the particles size distribution of the treated fly ash was similar to the particle size distribution of the Sisimiut clay, although the Sisimiut clay had a slightly higher fraction of finer particles. Teglværk clay (T), on the other hand, had a larger volume percentage of coarse particles than the fly ashes and the Sisimiut clay. According to the Unified Soil Classification System (USCS) (ASTM D2487-17) both clays are classified as fine-grained soils (silt and clay) as more than $50 \%$ of the volume contains particles with fraction $\mathrm{d}<75 \mu \mathrm{m}$. For both clays, the clay fraction $(<2 \mu \mathrm{m})$ was about $10 \%$ of their total volume, while approximately $45 \%$ of the volume of Teglværk clay and $65 \%$ of Sisimiut clay consisted of silt and 45\% and 25\% for Teglværk clay and Sisimiut clay was sand, respectively. Finally, the raw fly ash consisted of finer particles than the treated fly ashes (E and D) and the two clays, possibly related to the removal of the salts. The removal of small salt particles was seen in SEM photos by Chen et al. [21] for electrodialytic treated MSWI fly ash compared to raw ash. Taking into consideration the liquid limit $\left(\mathrm{W}_{\mathrm{L}}\right)$ and plasticity index $\left(\mathrm{I}_{\mathrm{P}}\right)$ of the clays as well as their particle size distribution according to the Casagrande plasticity chart [23], Teglværk clay is characterized as sandy lean clay, while Sisimiut clay as lean clay with sand. 
The XRD diffractograms of clays and fly ashes are shown in Fig. 2. As shown in the diffractogram, of Teglværk clay, this clay sample was dominated by quartz $\left(\mathrm{SiO}_{2}\right)$ and calcite $\left(\mathrm{CaCO}_{3}\right)$, and it also consisted of feldspars (albite $\left(\mathrm{NaAlSi}_{3} \mathrm{O}_{8}\right)$ and microcline $\left(\mathrm{KAlSi}_{3} \mathrm{O}_{8}\right)$ as well as micas (muscovite $\left(\mathrm{KAl}_{2}\left(\mathrm{AlSi}_{3} \mathrm{O}_{10}\right)\right)$. Sisimiut clay, on the other hand, consisted mainly of quartz and did not contain any calcite. Instead, the second most dominant mineral phase in the Sisimiut clay was feldspars (albite, microcline and anorthite $\left.\left(\mathrm{CaAl}_{2} \mathrm{Si}_{2} \mathrm{O}_{8}\right)\right)$, followed by amphibole (magnesiohornblende) and Fe - rich mica (phlogopite). This explains the light grey colour of the Danish clay due to calcite, in comparison with the dark grey of the Greenlandic clay. The main clay minerals in the Sisimiut region are illite followed by expandable clays and smectites [24] and for Danish samples the main clay minerals are typically found in the order of kaolinite, smectites and illite [25]. As for the fly ashes, the raw fly ash was dominated by the salts halite $(\mathrm{NaCl})$ and sylvite $(\mathrm{KCl})$. It also contained calcite and anhydrite $\left(\mathrm{CaSO}_{4}\right)$ as minor mineral phases. The two electrodialytically treated fly ashes (D and E) showed identical mineralogy. As shown from their diffractograms they were calcareous but, unlike the raw fly ash, they did not contain salts. Also, the phase of anhydrite (basanite) intensified in the electrodialytically treated ashes compared to the raw fly ash and traces of melilite mineral phases (gehlenite) were identified. It shows that the electrodialytic treatment is responsible for the removal of the salts in fly ashes D and E. Apart from removing salts, the electrodialytic treatment for one week also removed 1. $5 \% \mathrm{Cu}$ and $\mathrm{Pb}, 11 \%$ As and $\mathrm{Cd}, 27 \% \mathrm{Cr}$ and $\mathrm{Zn}$ from the fly ash [22]. The simultaneous extraction of metals is the advantage of electrodialytic treatment over water washing, which can only be efficient for metal removal if the water washing is combined with acid addition or bioleaching [26]. Based on the similar particle size distribution and mineralogy, it was determined to mix the two electrodialytically treated ashes for the further experiments. 
Total Ca and heavy metal concentration as well as leaching of heavy metals, chloride and sulphate were measured for the clays, raw fly ash and the mixture of the two treated fly ashes (Table 4). The values are compared to the limits given by the Danish Ministry of Environment for use in geotechnical applications [27], as no limits exist for the use of waste in construction materials. The limits are divided into three categories, based on the total metal content and metal leaching concentrations; Category 1 (free use), Category 2 (some use) and Category 3 (restricted use). Category 3 presents the highest range of accepted leaching concentrations for the most restricted use of a waste material in geotechnical applications. There are no upper limits on the total metal content in Category 3. The total metal concentrations showed a significant reduction in the total content of heavy metals in the fly ash due to the electrodialytic treatment, but the leaching of $\mathrm{Cr}$ and $\mathrm{Zn}$ increased, also to above the Category 3 limit. There was a significant reduction in the chloride and sulphate leaching, linked to the dissolution and removal of chloride and sulphate containing minerals and species during the electrodialytic treatment. The total content of heavy metals in the clays was significantly lower than in the fly ash samples, and metal leaching was not detected from the clay samples. The most significant difference between the two clays was the much higher Ca content in the Teglværk clay sample, which was also supported by that calcite was present in this clay and not in the Sisimiut clay sample.

\subsection{Characteristics of the clay discs}

The produced discs are shown in Fig. 3. It is seen that as the amount of the fly ash increased the colour of the discs got paler, both for the Danish (Teglværk) and the Greenlandic (Sisimiut) clay mixtures. The stronger red colour of the Sisimiut S0 disc is probably linked to the Feminerals that were identified in this clay. There was a difference in the colour of the discs with raw fly ash and electrodialytically treated fly ash. In the discs with Teglværk clay, the discs with raw fly ash were paler than the discs with electrodialytically treated fly ash, whereas the 
opposite was seen for the Sisimiut clay disc. This indicates that the resulting coulour of the discs is dependent both on the clay and the fly ash.

The total loss of mass, total linear shrinkage, total volume change, porosity, dry density and water absorption (from equations 1-6) of the produced discs are shown in Fig. 4. The total volume change (Fig. 4a) of the discs containing raw fly ash (R) was negative for both types of clays, meaning that these discs expanded instead of shrinking as the other discs did, and the expansion increased with increasing the amount of fly ash. This could be attributed to the bloating effect. The bloating effect is the basis for the production of lightweight aggregated. Bloating is caused by gas liberation from the decomposition of mineral phases such as sulphates or carbonate in clays during sintering, at the same time as glassily phases are produced that trap the gas and the clay expands [28]. The two clays investigated here were not bloating clays. The bloating was only observed when the raw fly ash was used in the clay discs. This suggests that it is not carbonates of the clays nor in the fly ash that is causing the bloating of these clay discs. If the carbonate was causing the bloating, bloating should also be observed of the clay discs with treated fly ash. It is, therefore, more likely that the bloating is caused by sulphates. Both the raw and the electrodialytically treated fly ash contained sulphates, however electrodialytic treatment reduced the amount of leachable sulphate (as seen in Table 4), and this might be to a level where bloating will not occur. Increasing the sintering temperature has also shown to reduce this bloating effect [16], but the influence of secondary resources on bloating properties when used in clay-based materials should be studied further.

A lower mass loss (Fig. 4b) but a higher linear shrinkage (Fig. 4c) were seen for the Sisimiut clay discs compared to Teglværk clay discs. This is clearly linked to the results of porosity (Fig. 4d), water absorption (Fig. 4e) and dry density. The porosity (Fig. 4d) and water absorption (Fig. 4e) increased by the addition of fly ash for both clay and fly ash types. Teglværk clay discs showed the highest porosity for substitution with raw fly ash, which is also linked to the 
higher mass loss for these clay discs compared to the Sisimiut clay discs. Generally, the porosity was higher when treated fly ash was added, with corresponding lower densities of the discs and higher water absorption, even if bloating occurred for the clay discs with raw ash. The water absorption was lower for all Sisimiut clay discs than for the Teglværks clay discs, also linked to the porosity. The clay discs were too small for measuring the compressive strength, whereas the density (Fig. 4f) can give an indication of the compressive strength, as density and strength are proportional. It is therefore expected that the compressive strength will decrease with increasing amount of fly ash in the clay disc, which is also seen in other studies $[15,17]$. In bricks used in the building industry, typical ranges are for technical properties are: dry densities $1610-2120 \mathrm{~kg} / \mathrm{m}^{3}$ [29,30]; open porosities 18.8-39 \% [30] and water absorption 22-37\% [31]. Compared to these ranges, only the water absorption was lower for some of the samples in this study, especially for the discs with Sisimiut clay and raw fly ash. The low water absorption could be due to the formation of glassy phases in the clay discs during firing that will result in a more compact disc [32]. When glassy phases are formed, the particles of the material are drawn together, reducing the packing voids between the particles and resulting in a lower porosity and water absorption [32,33]. Formation of glassy phases, especially for the discs with Sisimiut clay, could therefore be indicated by the higher linear shrinkage together with a lower porosity in these discs. For the discs with electrodialytically treated fly ash, there was a difference when using Teglværk or Sisimiut clay. The porosity and water absorption were higher with Teglværk than the Sisimiut clay, which is also linked to the properties of the clays themselves. The low porosity, high density and low water absorption for the Sisimiut clay discs indicate good performance in cold climates. When using electrodialytically treated fly ash, a 10 \% substitution of clay with fly ash gave the best results concerning porosity and water absorption compared to using raw ash. However, the pore size should be studied further to evaluate the possibility of resisting frost/thaw cycles. 
The diffractograms of the discs made of Teglværk clay and treated fly ash in different proportions is shown in Fig. 5 and for discs made of Sisimiut clay in Fig. 6. The reference discs with Teglværk clay, without the addition of fly ash, contained mainly quartz and feldspars (albite, microcline) as well as traces of melilite. As the amount of treated fly ash increased in the Teglværk clay discs, the peak intensity of quartz decreased significantly, since the treated fly ash did not contain quartz. In the discs with Sisimiut clay, quartz was also the dominant mineral but feldspars (albite and microcline) were also abundant. Moreover, pyroxene was found in the Sisimiut reference disc and the peak intensity increased by the addition of fly ash The occurrence of hematite in the Sisimiut discs, especially the reference disc with only clay, justifies the red colour of the Sisimiut clay discs, unlike the yellowish colour of the Teglværk clay discs where there was no presence of an iron-based minerals.

Table 5 shows the leaching properties of the brick discs. There is no clear pattern in increased metal leaching with increasing addition of fly ash; however, the leaching was made one single disc sample for each mixture, and the results are thus only indicative. All leaching results for $\mathrm{Cd}$ and $\mathrm{Pb}$ were below the detection limit. $\mathrm{Cr}, \mathrm{Cu}$ and $\mathrm{Zn}$ leaching were detected from some of the samples, and the leaching of $\mathrm{Cu}$ and $\mathrm{Zn}$ was below both the Category 3 guideline limit and also the guideline limit for disposal of inert waste, which represents an end-of-life guideline limit [34]. Cr leaching from the TED10 sample (pH 11.2) was above the Category 3 guideline limit and from TED20 (pH 10.7) above the inert waste guideline limit. Cr leaching was observed for almost all of the Teglværk clay discs with MSWI fly ash, but not from the any of the Sisimiut clay discs. This could be caused by the lower $\mathrm{pH}$ in the Sisimiut clay discs with MSWI fly ash $(\mathrm{pH} \leq 10.1)$ combined with the lower Ca content in the Sisimiut clay. Heavy metal leaching is highly pH-dependent, and it has been shown that $\mathrm{Cr}$ leaches 10 - $35 \%$ of the total $\mathrm{Cr}$ content in the $\mathrm{pH}$ range between 8-12 in Greenlandic MSWI fly ash, compared to neglectable leaching levels for other metals in the same pH range [19]. Additionally, Chen et 
al. [35] proposed that there would be less available $\mathrm{Ca}$ for the formation of soluble $\mathrm{CaCrO}_{4}$ during thermal treatment when Ca is removed from MSWI fly ash by electrodialytic treatment. This resulted in lower $\mathrm{Cr}$ leaching from a combined electrodialytically and thermal treated MSWI fly ash compared to MSWI fly ash with a higher Ca content [35]. This could explain the higher Cr leaching from the Teglværk clay discs with MSWI fly ash in this study since the Ca content in Tegværk clay was a factor 10 higher than in the Sisimiut clay that could be available for forming the soluble $\mathrm{CaCrO}_{4}$ during firing.

The availability of the metals was calculated as the leaching concentration divided by the total metal concentration. This was calculated for the raw and treated ash, as well as from the clay disc. For the clay dics, the total metal concentration was adjusted to the percentage of ash used in the disc, assuming only the fly ash part to result in leaching. To evaluate if the firing immobilized or mobilized the metals, the availability of the metal in the clay disc was divided by the availability in the ash [36]. The mobility indicates the extent of the immobilisation of the metals when fly ash is used in bricks in comparison with the metals' leaching from the fly ashes. If this number is below 1, it indicates an immobilization of the metal in the clay disc, and if this number is above 1 , it indicates a mobilization of the metal in the firing process. The mobility numbers are shown in the parentheses in Table 5. Belmonte et al. [20] observed increased mobility of As and Cr in clay discs containing $20 \%$ and $40 \%$ pre-treated MSWI fly ash by washing and electrodialytic treatment. The contrary was observed in this study, were all samples showed immobilisation in the clay matrix, except for two samples. In TED10 the Cr and $\mathrm{Cu}$ leaching increased and in TED20 the $\mathrm{Cu}$ leaching increased compared to the initial leaching of the ED fly ash. Chen et al. [21] studied the incorporation of electrodialytically treated MSWI fly ash in $5 \times 5 \times 5 \mathrm{~cm}^{3}$ bricks and found that leaching of heavy metals both in batch leaching (determined by DS/EN 12457-1) and total leachability (determined by the Dutch leaching test at $\mathrm{pH}$ 4) was below the regulatory standards for these tests. Leaching of As, $\mathrm{Hg}$, 
$\mathrm{Pb}$ and $\mathrm{Zn}$ exceeded the guideline limits for raw MSWI fly ash, which was reduced to only $\mathrm{Hg}$ and $\mathrm{Pb}$ in green bricks with MSWI fly ash and eliminated in sintered bricks by using two different leaching test regimes [15]. Nevertheless, care should be taken when comparing leaching results, as heavy metal leaching is highly $\mathrm{pH}$-dependent and different leaching tests are performed at different $\mathrm{pH}$.

Pre-treatment by electrodialytic treatment was efficient for reducing the total heavy metal concentration in the MSWI fly ash. The leaching in the fly ash itself increased for $\mathrm{Cr}$ and $\mathrm{Zn}$ but reduced the leaching of $\mathrm{Cd}, \mathrm{Cu}$ and $\mathrm{Pb}$. To reduce the leaching of all metals, the experimental conditions of the electrodialytic treatment should be optimised.

\section{Conclusions}

The clay sample used for commercial manufacturing of bricks consisted mainly of the minerals quartz, calcite, feldspars and mica, whereas the Sisimiut clay sample consisted of quartz, feldspars, amphibole and mica. The mineral phases of the MSWI fly ashes was mainly of calcite and anhydrite and in the raw fly ash also halite and sylvite. The clay discs with Sisimiut clay presented a reddish colour compared to commercial clay, which gave a white/greyish colour. Hematite was detected in the clay discs with Sisimiut clay, which could give the red colour in these clays discs. Leaching of Cr from raw and treated fly ash exceeded the limits of Danish regulation for waste in construction. The treated fly ash presented lower heavy metal concentration than the raw fly ash. Most heavy metals were incorporated into the brick matrix after firing, and the leaching and mobility of metals mainly decreased. Expansion of the discs occurred for the samples containing raw fly ash, caused by bloating due to gas formation from the decomposition of minerals during firing. The expansion increased with the increased amount of raw fly ash in the clay discs. The porosity and water absorption increased with the addition of more fly ash, while dry density decreased. The clay discs with Sisimiut clay showed 
the lowest porosity and water absorption. The electrodialytically treated MSWI fly ash showed good environmental performance in the clay brick discs and the treatment eliminated the bloating issue. Furthermore, using the Greenlandic clay in the discs resulted in lower porosity and water absorption than the Danish clay, so there is a potential for using these Greenlandic raw materials in bricks, to support local production of construction material.

\section{Acknowledgement}

Sabina June Hviid is thanked for help with the ICP and IC analysis and Erasmus + is acknowledged for providing a scholarship for Lorena Skevi.

\section{References}

[1] M.J. Quina, E. Bontempi, A. Bogush, S. Schlumberger, G. Weibel, R. Braga, V. Funari, J. Hyks, E. Rasmussen, J. Lederer, Technologies for the management of MSW incineration ashes from gas cleaning: New perspectives on recovery of secondary raw materials and circular economy, Sci. Total Environ. 635 (2018) 526-542.

[2] T. Sabbas, A. Polettini, R. Pomi, T. Astrup, O. Hjelmar, P. Mostbauer, G. Cappai, G. Magel, S. Salhofer, C. Speiser, Municipal Solid Waste Incineration Residues, Waste Manage. 23 (1) (2003) 61-88.

[3] H. Luo, Y. Zeng, Y. Cheng, D, He, X. Pan, Recent advances in municipal landfill leachate: A review focusing on its characteristics, treatment, and toxicity assessment, Sci. Total Environ. (2020) https://doi: 10.1016/j.scitotenv.2019.135468.

[4] N. Moreno, X. Querol, J. Andrés, K. Stanton, M. Towler, H. Nugteren, M. JanssenJurkovicová, M. Jones, Physico-chemical Characteristics of European Pulverized Coal Combustion Fly Ashes, Fuel 84 (11) (2005) 1351-1363.

[5] L. Muhmood, S. Vitta, D. Venkateswaran, Cementitious and pozzolanic behavior of electric arc furnace steel slags, Cem. Concr. Res. 39 (2009) 102-109.

[6] P. Muñoz Velasco, M.P. Morales Ortíz, M.A. Mendívil Giró, L. Muñoz Velasco, Fired clay bricks manufactured by adding wastes as sustainable construction material - A review, Constr. Build. Mater. 63 (2014) 97-107.

[7] S.P. Raut, R.V. Ralegaonkar, S.A. Mandavgane, S.A. Development of sustainable construction material using industrial and agricultural solid waste: A review of waste-create bricks, Constr. Build. Mater. 25 (2011) 4037-4042.

[8] M.J. Quina, J. C. Bordado, R.M. Quinta-Ferreira, Treatment and use of air pollution control residues from MSW incineration: An overview, Waste Manag. 28 (2008) 2097-2121.

[9] L. Zhang, Production of bricks from waste materials - A review, Constr. Build. Mater. 47 (2013) 643-655. 
[10] S.N. Monteiro, C.M.F. Vieira, On the production of fired clay bricks from waste materials: A critical update, Constr. Build. Mater. 65 (2014) 599-610.

[11] Z. Zhang, Y.C. Wong, A. Arulrajah, S. Horpibuluk S, A review of studies on bricks using alternative materials and approaches. Constr. Build. Mater. 188 (2018) 1101-1118.

[12] A. Al-Fakih, B.S. Mohammed, M.S. Liew, E. Nikbakht, Incorporation of waste materials in the manufacture of masonry bricks: An updated review, J. Build. Eng. 21 (2019) 37-54.

[13] H. Xinghua, Z. Shujing, J.Y. Hwang, Physical and Chemical Properties of MSWI Fly ash, in: S.J. Ikhmayies, B. Li, J.S. Carpenter, J.Y. Hwang, S.N. Monteiro, J. Li, D. Firrao, M. Zhang, Z. Peng, J.P. Escobedo-Diaz (Eds.), Characterization of Minerals, Metals, and Materials, Springer, Cham, 2016, pp. 451-459.

[14] H. Zhang, J. Qi, Reuse of air pollution control ash, Environ. Eng. Sci. 29 (9) (2012) 902906.

[15] Z. Haiying, Z. Youcai, Q. Jingyu, Utilization of municipal solid waste incineration (MSWI) fly ash in ceramic brick: product characterization and environmental toxicity, Waste Manag. 31 (2011) 331-341.

[16] Y. Deng, B. Gong, Y. Chao, T. Dong, W. Yang, M. Hong, X. Shi, G. Wang, Y. Jin, Z.G. Chen, Sustainable utilization of municipal solid waste incineration fly ash for ceramic bricks with eco-friendly biosafety, Mater. Today Sustain. 1-2 (2018) 32-38.

[17] V. Voisiene, O. Kizinievic, V. Kizinievic, Feasibility study of using clay bricks made from municipal solid waste incineration (MSWI) fly ash, IOP Conf. Ser.: Mater. Sci. Eng. 603 022058 (2019). https://doi:10.1088/1757-899X/603/2/022058.

[18] G.M. Kirkelund, C. Magro, P. Guedes, P.E. Jensen, A.B. Ribeiro, L.M. Ottosen,

Electrodialytic removal of heavy metals and chloride from municipal solid waste incineration fly ash and air pollution control residue in suspension - test of a new two compartment experimental cell, Electrochim. Acta 181 (2015) 73-81.

[19] G.M. Kirkelund, P.E. Jensen, Electrodialytic treatment of Greenlandic municipal solid waste incineration fly ash, Waste Manag. 80, (2018) 241-251.

[20] L.J. Belmonte, L.M. Ottosen, G.M. Kirkelund, P.E. Jensen, A.P. Vestbø, Screening of heavy metal containing waste types for use as raw material in Arctic clay-based bricks, Environ. Sci. Pollut. Res. 25 (2018) 32831-32843.

[21] W. Chen, E. Klupsch, G.M. Kirkelund, P.E. Jensen, L.M. Ottosen, C. Dias-Ferreira, Recycling of MSWI fly ash in clay bricks-effect of washing and electrodialytic treatment, in: C. Vilarinho, F. Castro, M.D. Lopes (Eds.), WASTES - Solutions, Treatments and Opportunities II, Taylor \& Francis, 2018, pp. 183-189.

[22] G.M. Kirkelund, P.E. Jensen, L.M. Ottosen, K.B. Pedersen, Comparison of two- and three compartment cells for electrodialytic removal of heavy metals from contaminated material suspensions, J. Hazard. Mater. 367 (2019) 68-76.

[23] A. Casagrande, Classification and identification of soils, Transact. Am. Soc. Civil Eng. 113 (1948) 103-112.

[24] L.J.Belmonte, Use of Greenlandic resources for the production of bricks, $\mathrm{PhD}$ thesis, DTU Civil Engineering, Technical University of Denmark, 2014. 
[25] Miljøstyrelsen, Lermineralers evne til at sorbere og tilbageholde forureningskomponenter (in Danish), Report no. 1854, Danish EPA, 2016.

[26] A. Ferraro, I. Farina, M. Race, F. Colangelo, R. Cioffi, M. Fabbricino, Pre-treatments of MSWI fly ashes: a comprehensive review to determine optimal conditions for their reuse and/or environmentally sustainable disposal, Rev. Environ. Sci. Biotechnol. 18 (2019) 453-471.

[27] BEK nr. 1672 15/12/2016. Bekendtgørelse om anvendelse af restprodukter, jord og sorteret bygge-og anlægsaffald (in Danish), Danish Ministry of Environment and Food, 2016.

[28] C. Riley, Relation of chemical properties to the bloating of clays. J. Am. Ceram. Soc. 34, (1951) 121-128.

[29] M. Dondi, P. Principi, M. Raimondo, G. Zanarini, The thermal conductivity of brick produced with Italian clays, L’industria dei Laterizi 65 (2000) 309-320.

[30] M. Dondi, F. Mazzanti, P. Principi, M. Raimondo, G. Zanarini, Thermal conductivity of clay bricks, J. Mater. Civ. Eng. 16 (2004) 8-14.

[31] P. Domone, J. Illlson, Construction materials: their nature and behaviour, Spon Press London and New York, 2010.

[32] M. Anderson, Encouraging prospects for recycling incinerated sewage sludge ash (ISSA) into clay-based building products, J. Chem. Technol. Biotechnol. 77 (2002) 352-260.

[33] L.M. Ottosen, I.M.G. Berthelsen, P.E. Jensen. G.M. Kirkelund, Sewage sludge ash as resource for phosphorous and material for clay brick manufacturing, Constr. Build. Mater. 249 (2020) 118684.

[34] BEK nr. 719 24/06/2011. Bekendtgørelse om deponerinsanlæg (in Danish), Danish Ministry of Environment and Food, 2011.

[35] C. Wan, G.M. Kirkelund, P.E. Jensen, L.M. Ottosen, Comparison of different MSWI fly ash treatment processes on the thermal behavior of $\mathrm{As}, \mathrm{Cr}, \mathrm{Pb}$ and $\mathrm{Zn}$ in the ash, Waste Manag. 68 (2017) 240-251.

[36] V. Karius, K. Hamer, pH and grain-size variation in leaching tests with bricks made of harbour sediments compared to commercial bricks, Sci. Total Environ. 278 (2001) 73-85. 
Table 1 Experimental materials.

\begin{tabular}{c|l} 
Clay & Symbol \\
\hline Teglværk (Danish clay) & $\mathrm{T}$ \\
Sisimiut (Greenlandic clay) & $\mathrm{S}$ \\
Fly ash & \\
\hline Treated fly ash (2 compartments) & $\mathrm{E}$ \\
Treated fly ash (3 compartments) & $\mathrm{D}$ \\
Mix E and D fly ashes & $\mathrm{ED}$ \\
Untreated (Raw) Sisimiut fly ash & $\mathrm{R}$
\end{tabular}


Table 2 Composition of the clay mixtures with the amount of fly ash given in wt\%.

\begin{tabular}{|c|c|c|c|c|c|}
\hline Sample name & $\mathrm{T}$ & $\mathrm{S}$ & $E$ & $\mathrm{D}$ & $\mathrm{R}$ \\
\hline T0 & 100 & & & & \\
\hline TED10 & 90 & & 5 & 5 & \\
\hline TED20 & 80 & & 10 & 10 & \\
\hline TED30 & 70 & & 15 & 15 & \\
\hline TR10 & 90 & & & & 10 \\
\hline TR20 & 80 & & & & 20 \\
\hline TR30 & 70 & & & & 30 \\
\hline S0 & & 100 & & & \\
\hline SED10 & & 90 & 5 & 5 & \\
\hline SED20 & & 80 & 10 & 10 & \\
\hline SED30 & & 70 & 15 & 15 & \\
\hline TR10 & & 90 & & & 10 \\
\hline TR20 & & 80 & & & 20 \\
\hline TR30 & & 70 & & & 30 \\
\hline
\end{tabular}


Table 3 Geotechnical properties of the clays.

Clay Plastic Limit
Liquid Limit

$\mathrm{W}_{\mathrm{L}}(\%)$

28.5

22.5
Plasticity Index

IP (\%)

Teglværk

15.2

14.2

Sisimiut 
Table 4 Metal concentration and leaching of the experimental material.

\begin{tabular}{|c|c|c|c|c|c|}
\hline & Teglværk & Sisimiut & Raw ash & ED ash & Category 3 [27] \\
\hline \multicolumn{6}{|c|}{ Total concentration (mg/kg) } \\
\hline Ca (g/kg) & 65 & 6.9 & 21 & 10 & \\
\hline Cd & $>2$ & $>2$ & 162 & 132 & $>0.5$ \\
\hline $\mathrm{Cr}$ & 16 & 50 & 109 & 71 & $>500$ \\
\hline $\mathbf{C u}$ & 9 & 38 & 1,350 & 667 & $>500$ \\
\hline $\mathbf{P b}$ & 17 & 6 & 8,770 & 2,170 & $>40$ \\
\hline Zn & 33 & 59 & 21,600 & 8,680 & $>500$ \\
\hline \multicolumn{6}{|l|}{ Leaching } \\
\hline pH & 7.9 & 6.9 & 10.3 & 9.8 & \\
\hline $\mathrm{Cd}(\mu \mathrm{g} / \mathrm{L})$ & $>20$ & $>20$ & 1560 & 2 & $2-40$ \\
\hline $\operatorname{Cr}(\mu \mathrm{g} / \mathrm{L})$ & $>20$ & $>20$ & 550 & 1190 & $10-500$ \\
\hline $\mathrm{Cu}(\mu \mathrm{g} / \mathrm{L})$ & $>20$ & $>20$ & 120 & 33 & $45-2000$ \\
\hline $\mathrm{Pb}(\mu \mathrm{g} / \mathrm{L})$ & $>20$ & $>20$ & 397 & 35 & $10-100$ \\
\hline $\mathrm{Zn}(\mu \mathrm{g} / \mathrm{L})$ & $>20$ & $>20$ & 109 & 340 & $100-1,500$ \\
\hline $\mathrm{Cl}(\mathrm{mg} / \mathrm{L})$ & 34 & 34 & 155,000 & 1700 & $150-3,000$ \\
\hline $\mathrm{SO}_{4}(\mathrm{mg} / \mathrm{L})$ & 59 & 18 & 3400 & 750 & $250-4,000$ \\
\hline
\end{tabular}


Table 5 Leaching from the clay discs. *mobility of metals in clay discs normalized to the mobility of metal in the ash

\begin{tabular}{cccccccc}
\hline Sample & pH & $\mathbf{C d}(\boldsymbol{\mu g} / \mathbf{L})$ & $\mathbf{C r}(\boldsymbol{\mu g} / \mathbf{L})$ & $\mathbf{C u}(\boldsymbol{\mu g} / \mathbf{L})$ & $\mathbf{P b}(\boldsymbol{\mu g} / \mathbf{L})$ & $\mathbf{Z n}(\boldsymbol{\mu g} / \mathbf{L})$ & $\mathbf{C l}(\mathbf{m g} / \mathbf{L})$ \\
\hline T0 & 11.7 & $<20$ & $<20$ & $<20$ & $<20$ & $<20$ & 366 \\
TR10 & 10.1 & $<20$ & $53(* 0.96)$ & $<20$ & $<20$ & $<20$ & 34 \\
TR20 & 9.9 & $<20$ & $46(* 0.42)$ & $<20$ & $<20$ & $<20$ & 88 \\
TR30 & 9.8 & $<20$ & $74(* 0.45)$ & $<20$ & $<20$ & $<20$ & 116 \\
TED10 & 11.2 & $<20$ & $3240(* 27)$ & $33(* 10)$ & $<20$ & $31(* 0.91)$ & 155 \\
TED20 & 10.7 & $<20$ & $102(* 0.43)$ & $23(* 3.5)$ & $<20$ & $40(* 0.59)$ & 14 \\
TED30 & 9.9 & $<20$ & $<20$ & $<20$ & $<20$ & $80(* 0.78)$ & 26 \\
S0 & 10.9 & $<20$ & $<20$ & $<20$ & $<20$ & $<20$ & 13 \\
SR10 & 10.1 & $<20$ & $<20$ & $<20$ & $<20$ & $<20$ & 29 \\
SR20 & 9.7 & $<20$ & $<20$ & $<20$ & $<20$ & $<20$ & 111 \\
SR30 & 9.4 & $<20$ & $<20$ & $<20$ & $<20$ & $<20$ & 73 \\
SED10 & 9.9 & $<20$ & $<20$ & $<20$ & $<20$ & $33(* 0.97)$ & 11 \\
SED20 & 9.7 & $<20$ & $<20$ & $<20$ & $<20$ & $36(* 0.53)$ & 19 \\
SED30 & 9.6 & $<20$ & $<20$ & $<20$ & $<20$ & $38(* 0.37)$ & 18 \\
\hline Category 3 [27] & & $2-40$ & $10-500$ & $45-2000$ & $10-100$ & $100-1,500$ & $150-3,000$ \\
Inert waste [34] & & 15 & 100 & 450 & 100 & 1,000 & 275 \\
\hline
\end{tabular}




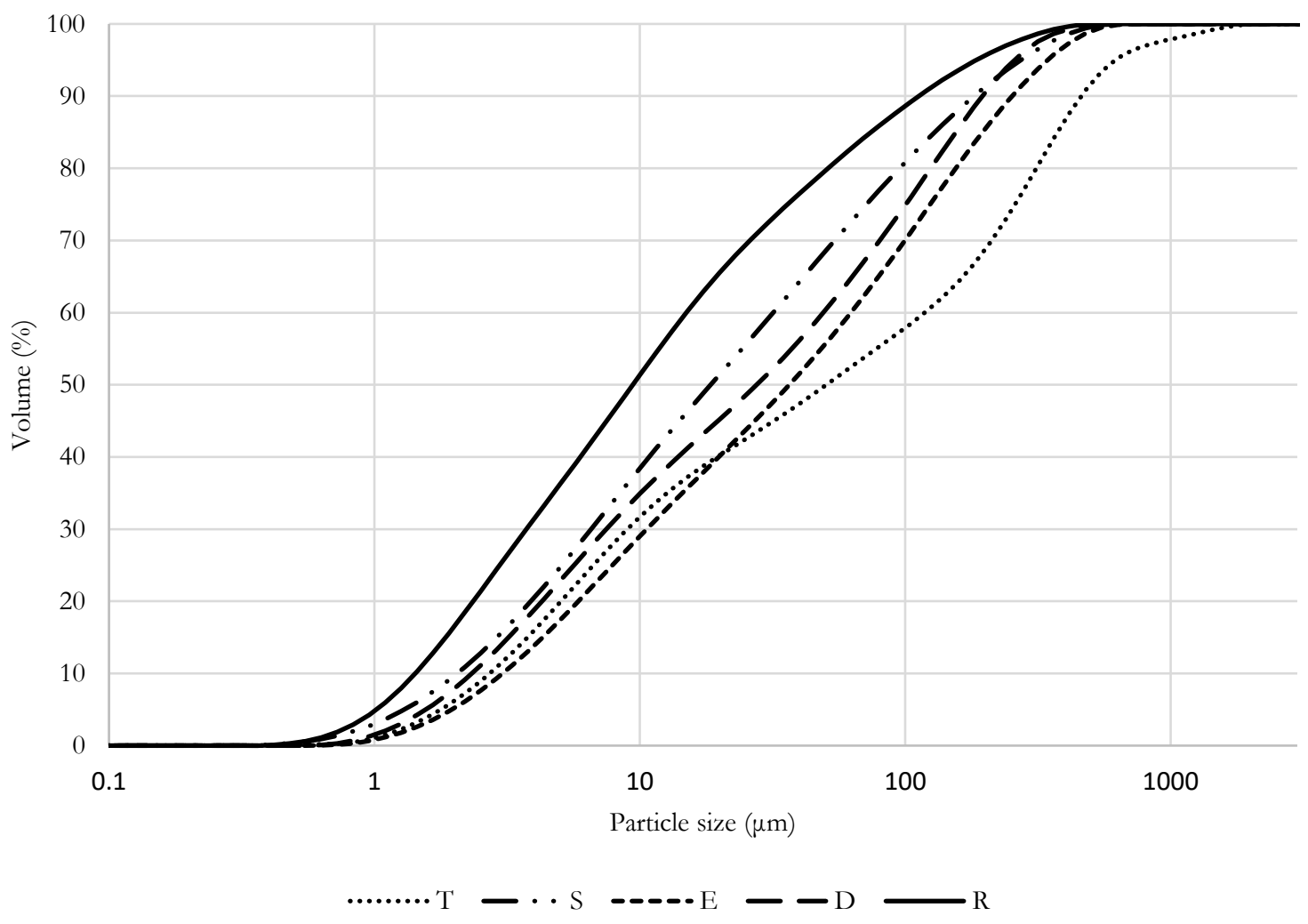

Fig. 1 Particle size distribution of Teglværk clay (T), Sisimiut clay (S), treated fly ashes (E\&D) and raw fly ash $(\mathrm{R})$. 


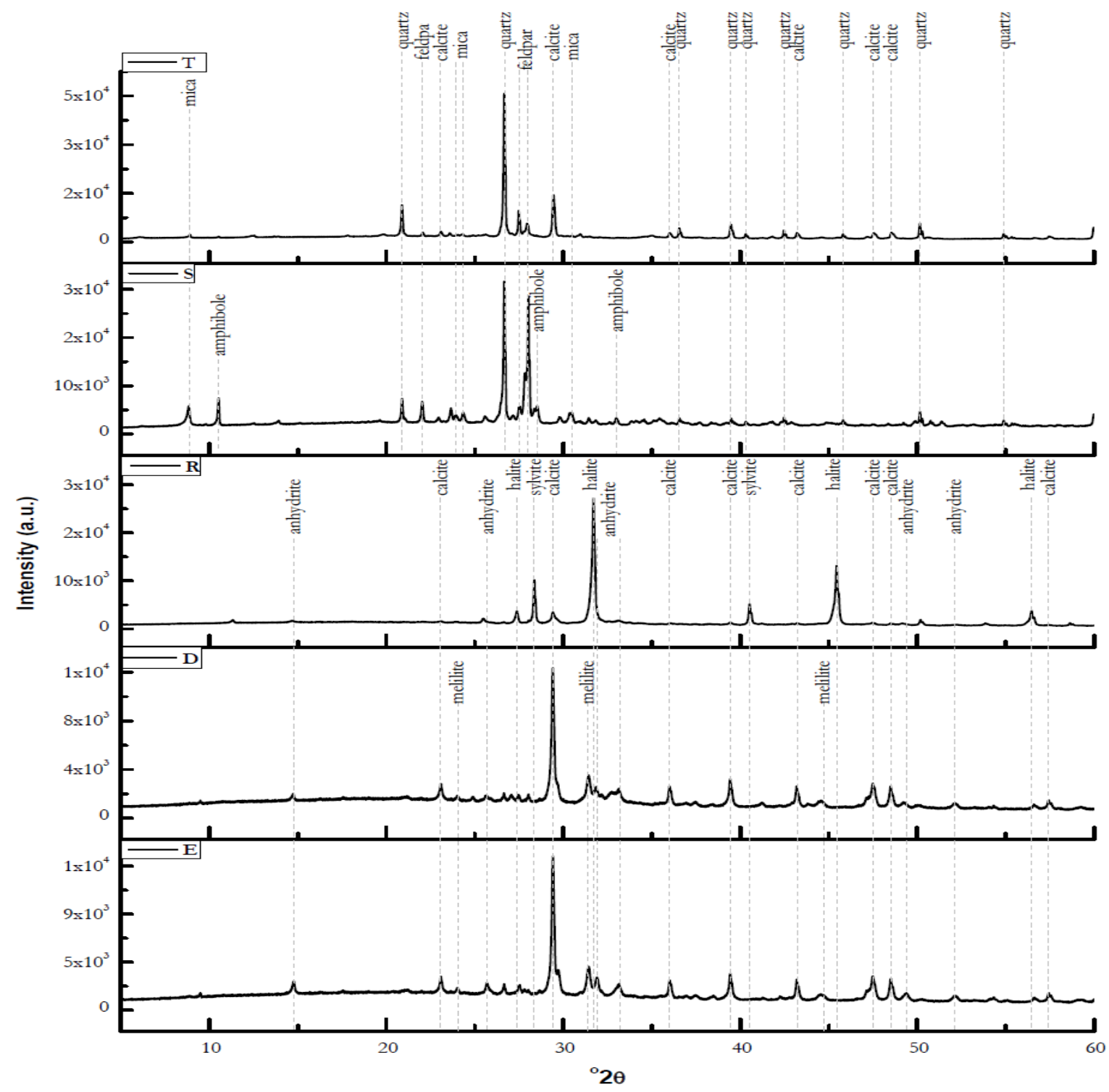

Fig. 2 X-ray diffractograms of the experimental materials Teglværk clay (T), Sisimiut clay (S), treated fly ashes (E\&D) and raw fly ash (R). 

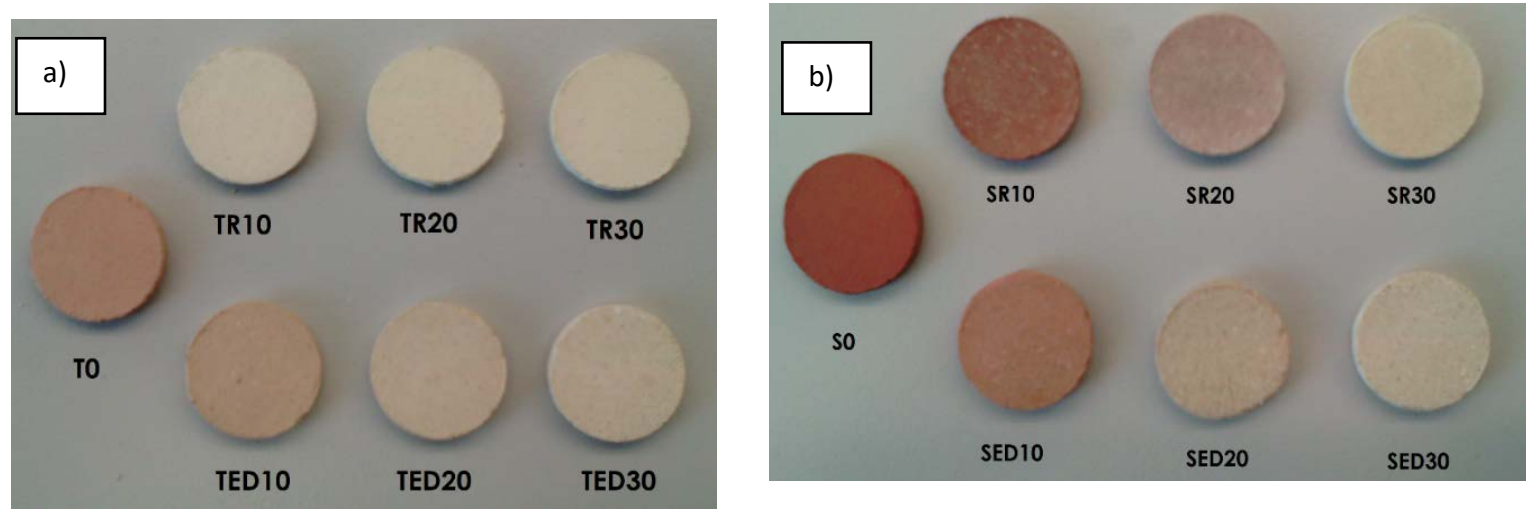

Fig. 3 Colours of discs with substitution of clay with different amounts $(0 \%, 10 \%, 20 \%, 30 \%)$ fly ash (R - raw, ED - treated). a) Teglværk (T) clay discs, b) Sisimiut (S) clay discs. 

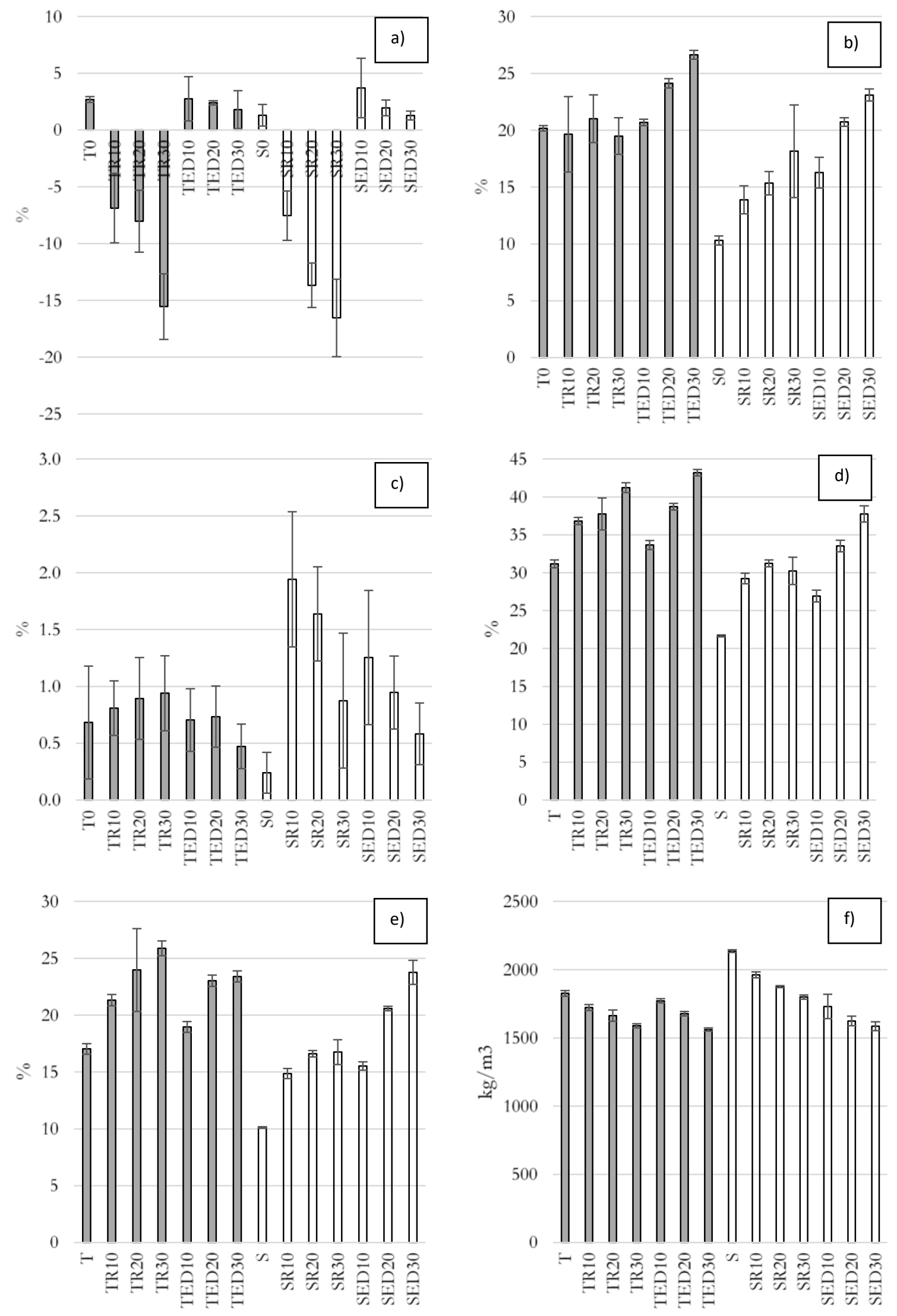

Fig. 4 Physical properties of the clay discs: a) total volume change, b) total mass loss, c) total linear shrinkage), d) porosity, e) water absorption f) dry density. 


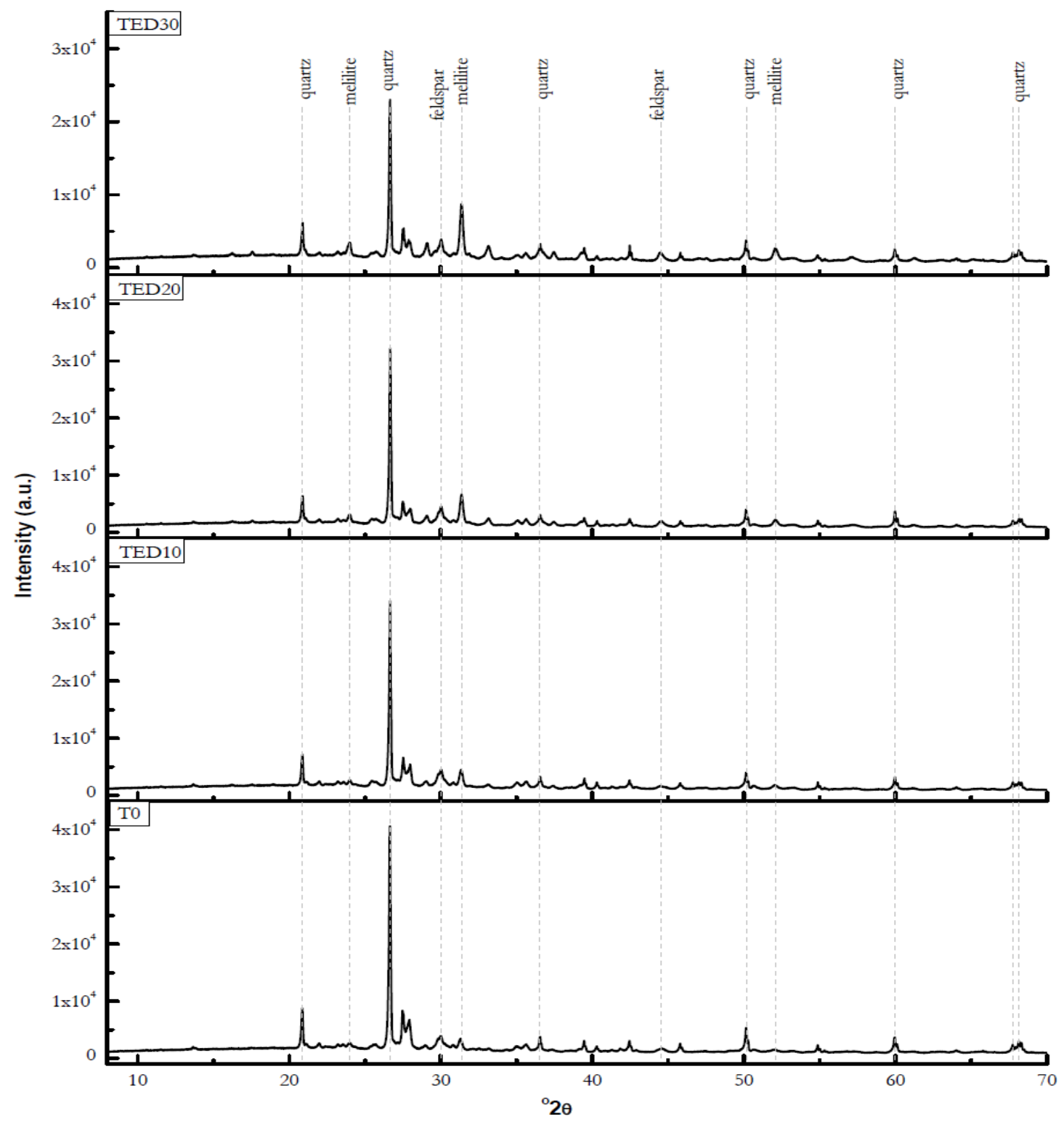

Fig. 5 Diffractogram of Teglværk (T) clay discs with treated fly ash substitution of clay at $0 \%$, $10 \%, 20 \%$ and $30 \%$. 


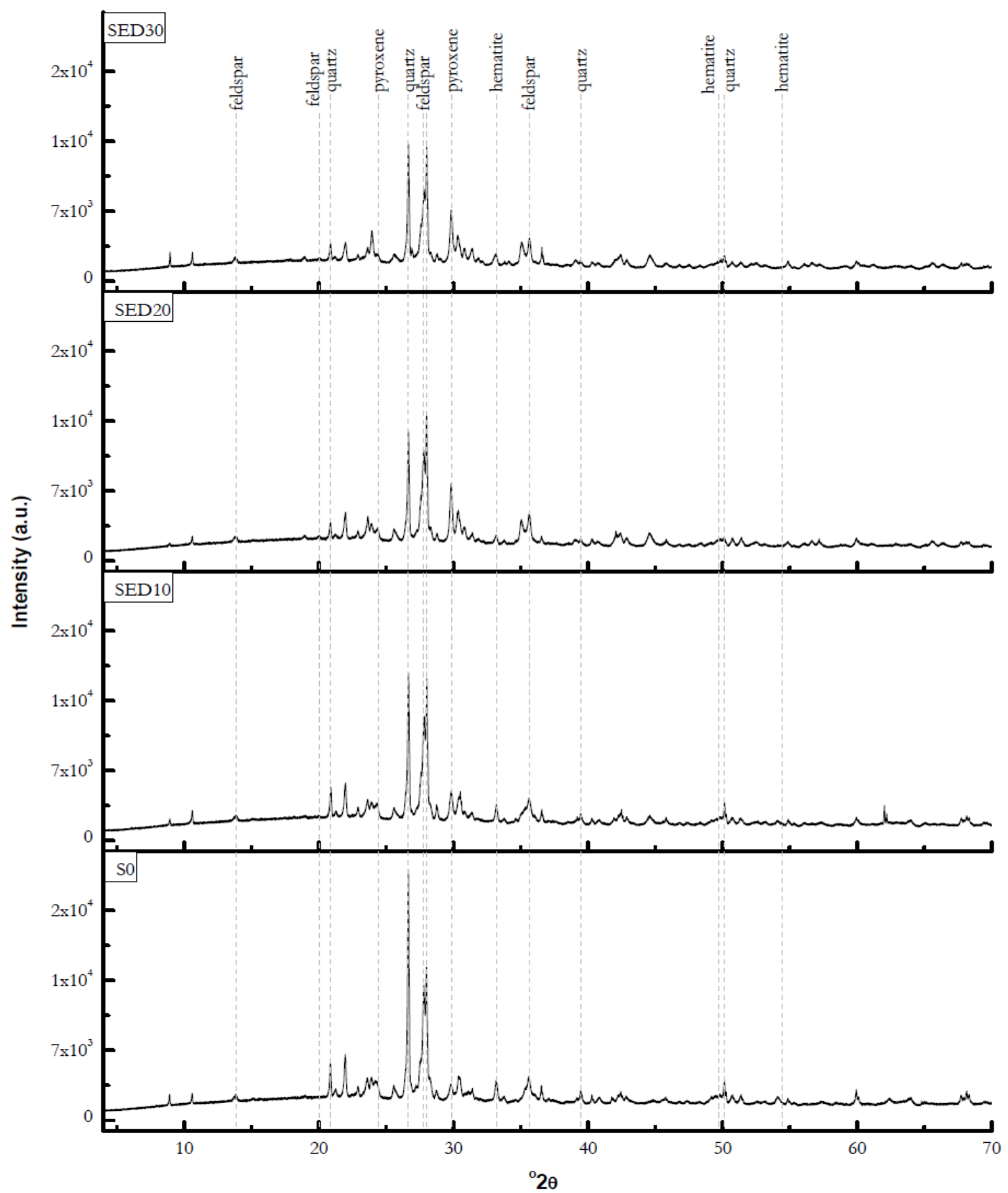

Fig. 6 Diffractogram of Sisimiut (S) clay discs with treated fly ash substitution of clay at $0 \%$, $10 \%, 20 \%$ and $30 \%$. 